\title{
Research on the Influence of Xunzi's "King and Hegemony" Thought on Han Dynasty's Politics
}

\author{
Zeyu Wang \\ Northwest Normal University, Gansu, Lanzhou, 730070
}

Keywords: scorption; kingdom; overbearing; politics; thought

\begin{abstract}
Wang Dao and hegemony are important contents in Confucian political philosophy theory. Xunzi has transformed it from a pure historical state to a highly theoretical political philosophy. This not only made Confucius and Mencius's conception of "kingdom" from philosophical ideals to political practice, but also provided a relatively complete political theory system for the emerging landlord class at that time, which made Wangba's thought more suitable for the current situation and more of the times. This article will start from the "Wang Ba miscellaneous" ideology of Xunzi, explore its practical achievements in Han Dynasty politics, and further reveal the theoretical ability of Xunzi's ruling thought in the face of the new situation, to partially compensate for the previous research.
\end{abstract}

\section{Overview of the Thought Content of Xunzi's "King and Hegemony"}

"Wang Dao" and "hegemony" as a pair of political concepts have been debated by the scholars of the dynasties since their appearance. The concept of "Wang Dao" expresses the recollection of the politics of the Holy King of Xia, Shang and Zhou Dynasties during the Warring States Period. It is obviously with an idealized color. Its basic connotation is to use the moral spirit to influence the world, thus bringing the hearts of the people to the heart. "Overbearing" refers to the achievements established during the Spring and Autumn Period "Five Pa". Its basic connotation is to dominate the princes with military strength. In general, Confucianism advocates the king, and Confucius and Mencius are the same. The scorpion is no exception, but in the specific historical environment of the Spring and Autumn and Warring States, the ideal of "Wang Dao" is farther and farther away from reality, and the hegemony that follows it becomes another scorpion in the era of the unbearable era of king politics. Therefore, in the book "Xunzi", hegemony is always proposed as a political option second to the king. The author will briefly discuss the kingdom thought and hegemonic thought of Xunzi.

First of all, let's talk about the king's thoughts. As the supreme ideal of Xunzi's political theory, Wang Dao's most fundamental requirement is that the ruler itself must have the highest morality. This is what the blind man said: "The Holy King." In this way, the ruler can rely on his own morality, benevolence, and prestige to command the world, so that the world can be reconciled without any armor. Xunzi's assertion that "the king has the power to win without war" is essentially the same as Mencius's “invincible benevolence”. This is more evident in the characteristics of Wang Daoguan. He said: "The country is calling for righteousness, and it is harmless. It is unjust, killing one without sin, and getting the world, the benevolent is not." Supporting the heart of the country, and if it is the solid, and the person who is the one who is the one who is the righteous person, the reason is that the person who is clothed in the national criminal law is also the law of righteousness; the Lord's place is extremely handsome and the first hometown If you are, then you will be motivated by the righteousness. If you go up to the righteousness, you will be determined by the law, and you will decide the country, the country will be fixed, and the world will be fixed. Zhongni has no place to set a cone, sincere and sincere, and the body is righteous. The words, the day of the economy, do not hide the world, the name belongs to the later generations. Today is also the princes of the world, the sincerity and ambition, the law of justice and the law, the case of the government the killing of the nobles makes the attacking end of the same. If so, then the reputation of the husband is also between the heavens and the earth. It's not as good as the sun and the moon! It's 
awkward: the country's Qiyi, one day and white, Tang Wu It is also. Tang Yizhen, Wu Wang Yizhen, are also the land of the hundred miles, the world is one, the princes are the ministers, the genus of Tongda, do not obey, no it is so blasphemy, Yiji. "In the eyes of Zi, Wang country should put" call of propriety and harmless "As a general principle governing the country, the monarch so that" justice is not a line, killing a innocent. "In the use of people, we must reuse the righteous. Etiquette is required when enacting laws. If Ming Junren can do the right to govern the country, then the country is naturally prosperous and strong. Therefore, the scorpion uses soup and Wu to explain that "Yi Li and Wang" is the highest ideal to end the troubled times. With the courtesy of the world, you will be able to "win without a battle, not break through the attack, not to work and the world."

Let me talk about the overbearing thoughts of Xunzi. Xunzi inherited Confucius and Mencius's moral expectations for the kingdom, and regarded "righteousness and kingship" as the basis for unifying the world. In Xunzi's view, hegemony is a transitional state between the king and the strong. In the chaotic world, when the king is difficult to continue, hegemony naturally becomes the best choice. Although it is not based on benevolence and righteousness, it does things in a benevolent manner, so that "the punishment has been promised to the world, and the ministers know that they can do it." It is much better to be the best in the name of the righteousness than to know the power of force. Although hegemony does not have the highest righteousness and righteousness, it can be "trusted" on the basis of strong strength. This hegemony is desirable in the eyes of the blind.

The scorpion is not the same as Mencius's rejection of hegemony. He believes that if a monarch can't realize the "king", it can be better to achieve "hegemony" than to let the country perish. Therefore, Xunzi has a positive attitude towards "king" and "hegemony." What is more noteworthy is that Xunzi recognized the dialectical relationship between "king" and "hegemony". In the concept of Xunzi, although the value of "king" is higher than "hegemony", the two are not completely opposite. Although "hegemony" is not the highest ideal, some measures and achievements of "hegemony" are the necessary conditions for the "king". Xunzi said: "Longli respects the sage and the king, and the law loves the people and hegemonizes"; "Yi Li and Wang, believes in the hegemony." "Wang Dao" needs "Liang Li Zun Xian" on "respecting the law and loving the people". On the basis of "trust", it is even more necessary to establish "righteousness". At the same time, although "Wang Dao" relies on benevolence and righteousness to serve people, it cannot be backed up by the military "wei" of "the world is not enemies." Both "Benevolence", "Yi", and "Wei" can "see the king and the king, want to hegemony, want to be strong and strong"; "can be king, can be hegemony". It can be seen that "kingdom" and "hegemony" are not completely repelling opposition, but can complement each other. Only "wangba miscellaneous use" can truly realize the unity and prosperity of the country.

\section{The Ways and Methods for Xunzi to Realize the Idea of "King and Hegemony"}

Taking the "king" ideal as a spiritual guide, "hegemony" is a realistic means of leading to kingdom politics. Xunzi proposed a series of methods to mix. First of all, it is to be a proper name. Xunzi is very appreciative of the hierarchical society, and all levels are safe and self-sufficient. So he wrote a special "Right Name" to discuss. In the eyes of the blind, the ceremony is not profitable. He said: "Lilong thinks extremely, and the world can not lose profit and loss." The connotation of the ceremony is that the nobles are different, young and old. Therefore, the nephew stressed the need to be a proper name. This is the only program in politics. He said: "The name is slow, the slogan is singular, the name is chaotic, and the shape of right and wrong is unknown. Although the law-abiding, the ruling Confucianism is also chaotic. If there is a king, it will follow the old name, there will be In the new name." Xunzi believes that the correct name is the most crucial step in the implementation of the king's politics, and to be "righteous", the most important thing is to "name", and to be "name-keeping", you need to do"

"The life of a person cannot be indiscriminate, the group does not divide, the competition is chaotic, the chaos is indiscriminate, and the chaos is poor. Therefore, there is no distinction, and the human beings are also greatly harmed; there are points, the world is also profitable; and the people 
are, therefore, the branch of the branch is also necessary. Therefore, the beauty is the essence of the beauty of the world; the person of peace is the foundation of the world; the person of the noble is the foundation of the world." The people of Shangli will not make points, this is a manifestation of gregariousness and a method different from birds and beasts. The essence of the thought of Xunzi's theory is to maintain the hierarchy of noble and noble, which is not only the essence of Xunzi's political thought, but also the result of the Confucian name.

Secondly, it is "the law of solemnity." This is the most important way to achieve "Wang Pa miscellaneous use." It can also be said that the most obvious externalization of "Wang Pa miscellaneous use" is "Long Qi and Heavy Law". In the norm of social order, Xunzi believes that the difference between "king" and "hegemony" lies in the emphasis on "king" and "overbearing". Xunzi creatively combines the two in political practice and puts forward the great idea of "long ritual and heavy law". Xunzi said: "Listen to the big points of politics: treat people with good deeds with courtesy, and treat them with inferiority with impunity. The two are not good or bad, and they are not chaotic. If you are not good, you will not be chaotic. If it is, the reputation is heard, the world is willing, the line is forbidden, and the king's things are completed." The scorpion advocates ritual and law, and rewards the good and the rule of law. Only when the rewards and punishments are clearly defined can we ensure that the talents and the mediocrity will not be mixed, and the right and wrong will not be confused. In this way, the rule of "kingdom" is not far away. At the same time, he further proposed the importance of the rule of law in state governance. In order to "become unfortunate, the people have no luck."

While emphasizing the rule of law, Xunzi also values rituals. Pay attention to the important role of moral education in governing the country. He said: "All who win will be with others. Those who win will also be with Germany. Why are the Taoists? Let the faithfulness be the same." It is learned that the monarchy must rule the country. As a guarantee of the system, the ritual and music education is placed in the first place. Otherwise, the country will be chaotic without rules, and the people will be rude, and the country will naturally perish.

In the relationship between ethics and criminal law, Xunzi also gave his own views. He said: "If you don't teach and swear, then you will be puzzling and sinful; if you don't teach, you will not punish the traitor. If you don't reward, then the people who are diligent will not persuade; if you don't like it, then you will be suspicious. Customs and dangers, but the people are not the same. Therefore, Wang Mingli first, one to the faithful to love, Shang Xian to enable the second, the lord to celebrate the reward to apply for it, when the matter, lightly to adjust If you are, then you will not be able to make a traitor, but the thief will not be able to do it, but the sorcerer will persuade him. Is it evil? Then its Daoyi, its solid, its decree, its defense shows. Therefore: "The last ten is the next one, the second is the second." If the grass is sturdy, the branches and leaves must be classified. "This is also true.

What Xunzi said is "If you don't teach, you will be guilty of crimes and evils. If you don't teach, you won't punish people." The level of ritual and law is not biased toward one side, and under the same conditions of governance. If the punishment is too heavy, it will lead to the spread of cool politics; if it is too biased towards education, it will breed corruption and laziness due to the light criminal law. The reward and punishment are not divided, and the people will be confused. Therefore, Xunzi believes that the implementation of the kingly system requires both ritual and law, and the ruler must be based on the ritual and the rule of law. Only by effectively combining the two can the entire country be effectively managed. Therefore, the "long ceremony and heavy law" is an effective means to realize "Wang Ba miscellaneous use", and it is also a concrete reflection of the "Wang Ba miscellaneous use" thought in the end of the Warring States.

\section{The Influence of Xunzi's "King and Hegemony" Thought on Ruling Thought of the Country in Han Dynasty}

In the early days of the founding of the Western Han Dynasty, the rulers learned the lessons of the demise of the Qin Dynasty. They believed that the demise of the Qin Dynasty was an extreme one-sided emphasis on hegemony and severe punishment, which ultimately led to the demise of the 
country. The rulers of the Han Dynasty used this as a guide to consciously or unconsciously promote the political measures of "Wang Ba miscellaneous use" in political practice. Since the founding of the monarch Liu Bang, he has already fulfilled the ideological idea of "Wang Ba miscellaneous use." In the eleventh year of Gaozu's eleventh year, there are sentences in which "the king is higher than Zhou Wen, the tyrant is higher than Qi, and the sage is famous." It can be seen that Liu Bang is very appreciative of the "Wang Ba miscellaneous use" thinking.

Later Han Wudi also continued to implement this ideological line. In the "Han Wudi Ji", there is such a record: "Xiaowu was first established, Zhuoran slammed a hundred, and the six chapters of the table, the domain of the sea, and the loyalty of the country, with its meritorious deeds, Xing Taixue, Xiujiao, Correction, fixed calendar, concerted rhythm, poetry, Jianfeng Zen, Li Baishen, Shao Zhou, the order article, can be described, after the flood of the Hong Kong industry, and three generations of the wind. The change of Wenjing's Gongyi to Ji Simin, although the poetry book said, how can it be crowned." It can be seen that Emperor Wu of the Han Dynasty can be accompanied by Wang Dao ethics while practicing the hegemonic criminal law, and continue to inject the idea of "Wang Pa miscellaneous use".

After the Salt and Iron Conference, the Han Xuan Emperor, who followed, clearly pointed out the influence of "Wang Ba miscellaneous use" on the politics of the Han Dynasty. He once said to the prince Liu Wei: "The Han family has its own system. It is based on the domineering of the king, and it is purely moral education. It uses Zhou Zhenghu." Han Xuan Emperor not only summed up the political wisdom of the former king and hegemony, but also consciously practiced. The political thought of "Wang Ba miscellaneous use" made "Wang Dao" and "Hegemony" play an extreme role in Xuan Emperor.

\section{The Influence of Xunzi's "King and Hegemony" Thought on Rites and Music Education in Han Dynasty}

As I said before, Xunzi believes that the most important way to achieve "Wang Ba miscellaneous use" is "Liang Li et al." After the rulers of the Han Dynasty decided to use the "Wang Ba miscellaneous use" as the strategy for governing the country, naturally, they also spared no effort to promote the "long ceremony". This runs through the politics of the Han Dynasty. According to the "Han Book of Criminal Law", "Love is to be respected and not defeated, and Dewei must be long-standing. Therefore, the ceremony is to reverence, and the punishment is to be used in Mingwei. The saints are both savvy and philosophical, and will pass the heavens and the earth." It can be seen that ethics and punishment played a vital role in the Han Dynasty. But even so, the nephews and Han rulers still believe that the status of "ritual" is higher than the status of "law." Dong Zhongshu once advised the Emperor Wu of the Han Dynasty: "The king is willing to engage in the work of God, and he will save the punishment for the moral education. The punishment can not be allowed to rule the world, and the yin of the yin can not be allowed to become the age of the age. And the desire to be turned into a sea, it is difficult to achieve."

It is the consistent tradition of Confucianism to attach importance to the rule of the country, and it is also the core of the kingly politics. "Rite" has a supreme status in Xunzi's political theory and is mentioned at the height of "the life of the country." In the Han Dynasty, this is still the case. In the Han Shu • Li Le Zhi said: "The six classics are the same, and the use of ritual and music is urgent. The person who is in charge of the body must be forgotten, then the storm is smashed into the country; once rude, it is ruined and ruined." It can be seen that ritual and ritualization still has an unshakable position in the Han Dynasty.

In the eyes of Xunzi, ritual music is the premise of the implementation of the king, and also the basis for the implementation of hegemony. In the "Fu" article, Xunzi once made a metaphor. There is a thing that "lives the life, the dead to the fun; the city Guo to the solid, the three military to the strong. The quintessence of the king, refuted the Bo, without a trip." ... to make a clear and covenant, very smooth and elegant." At the end of the article, the scorpion gave the answer by the king's mouth: "Please return to the ceremony." In the history of the Han Dynasty, ritual and law are still an inseparable whole. Although Emperor Wu of the Han Dynasty was established as a national 
orthodox ideology, in the specific political practice, the ruling policy of "outside Confucianism and internal law" was implemented. "Han·Li Lezhi" said: "The etiquette of the people, the music and the voice of the people, the government to do it, the punishment is to prevent it. The ritual and music of the four sects and shackles, then the king is ready."

In the same way, ethics also has an important role in restraining criminal law. Liu Xiang once said to Han Cheng: "The penalty is over, or it is to death or injury. The punishment of today is not the law of Tao, but the Secretary has to make a law, cut it, cut it, save it, and save time. As for ritual, then Dare, dare to kill and dare not raise people... The husband-in-law is better than the criminal law, the criminal law is light, and the house is heavy and eager to light. And the education, the ruling is the rule, the criminal law is also the help. It can be seen that in the aspect of ritual and music education, the rulers of the Han Dynasty unconsciously practiced the idea of "the king's miscellaneous use" of the scorpion, and better combined with reality to achieve the purpose of serving politics.

\section{The Influence of Xunzi's "King and Hegemony" Thought on the Ruling Policy of the Han Dynasty}

In the previous section, the author briefly discussed the side of the "long ceremony" in the "Lang Lie Heavy Law" of the Han Dynasty. "Han Shu Li Le Zhi" said: "And the education, the sorrow of the rule of law, the criminal law is also help." The ethics and the criminal law complement each other, mutual cooperation can achieve the king of the road. So below we focus on the content of "heavy law." It should be noted that the so-called "law" of Xunzi and the "law" mentioned today are not equal concepts. In the pre-Qin period, the law was only a method of sentenced and punished the prisoner. Later, it gradually included rewards for merit, and even the method of appointing the bureaucrats and the administrative orders of the monarch.

Both "ritual" and "law" contain the factors of "institution". Xunzi attaches importance to this "institutional factor" and believes that ideal social politics should be able to "make the people of the group and ministers all systemically." In the Han Dynasty, the "law" was institutionalized, and the concept of "law" was implemented. There is such a sentence in "Han Book and Criminal Law": "The ancients have words: they are born with five materials, and the people use it. If they can't afford it, who can go to the army? The whip can't be relaxed at home, the penalty can't be abolished in the country, and the punishment can't be It is in the world." Criminal law plays a vital role in stabilizing the country, so it is impossible to abandon the criminal law. Even Dong Zhongshu, who is wholeheartedly practicing Confucian political ideas, has to admit the important role of criminal law in governing the country. He said: "Where the king wants to do something, he should seek his end in heaven. The big man in heaven is in yin and yang. Yang is the virtue, Yin is the punishment... Yang is out of the cloth and is the master of the age. At the end of the day, he will be out of Zuoyang. Yang can’t help Yin, and he can't be alone.”

Although Xunzi agrees with the criminal law, it does not mean that he agrees with the abuse of punishment. He said: "If you don't want to be jealous, you don't want to abuse it." Both rewards and punishments should not be abused. If you are not sure, you will not be punished. The rulers of the Han Dynasty also firmly implemented the idea of the scorpion. According to the "Han Book and Criminal Law" records, the Emperor Wen of the Han Dynasty felt very deeply when he saw that he was saving his father. Once I wanted to abolish the corporal punishment, and then listened to the advice of Zhang Cang and Feng Jing, which greatly reduced the penalty. When it came to Jingdi, it was also stipulated: "The coronation is no different from the felony. Fortunately, it is not dead, it cannot be a person." After the squatting: "The coroner, or to the death of the unfinished, is very pity. It is reduced by three hundred and two hundred, two hundred and one hundred and one hundred." It can be seen that the rulers of the Han Dynasty did not advocate the abuse of punishment. It coincides with the idea that Xunzi's “crime does not want to abuse”.

In addition to the criminal law, the development of the economy and the military is also an important part of the idea of "the tyrants of the king." Xunzi believes that only economic and military strength may not make a country a great country that is respected by the world, but to 
become a great country, it must have strong economic and military strength. The so-called "the country of rape and violence makes it easy for the country of rape." Xunzi believes that "the king is rich and the tyrant is Fuji." The "king" society in Xunzi's ideal should be a society where the rich and the people are rich and the people are generally wealthy. The society of the tyrants is a society in which some people get rich first, that is, people above the level of "senior". When the king and the tyrant are used together, the whole country will be rich. Therefore, he advocated "saving the people, and hiding the rest. The festival is used for rituals, and the Yumin is in power." This is the "land of the country".

After the founding of the Western Han Dynasty, he learned the lessons of the demise of the Qin Dynasty and adopted the "saving the people" method to achieve the goal of "fostering the people." "Han·Food and Food" quoted a single sentence: "This king is light and heavy, and the people lose their capital. Can they be indifferent? If the people are jealous, the king will be lacking; Yu Min; if the people do not give it, there will be a distant ambition, and it will be a separation from the people." It can be seen that the rulers of the Han Dynasty have already realized that the scorpion "the lord of the Ming dynasty must cultivate its harmony, the festival, the source, and the discretion." There will be more than enough in the world, and there will be no shortage of worry. If so, then the top and bottom are rich, and there is no hiding. It is the truth of knowing the country." In terms of "savings", the most typical example is the Chinese Emperor. "Historical Records" records that the Emperor of the Han Dynasty "taste to make a terrace, call the craftsman to calculate it, straight 100 gold. Captain: "The production of the ten hundred Chinese people in the 100-year-old, I am the first imperial palace, often fearful, why is Taiwan!" Mrs. Shen Shen, the clothes can not be dragged, the credit can not be embroidered, to show Dunpu, for the world first." Become a model of the scorpion "the use of Yumin, the name of the benevolent sage."

In terms of "Yumin", the most effective implementation of the Han Dynasty is "small and thin." "Han·Food and Food" contains a paragraph of Dong Zhongshu's remarks to the Emperor Wu of the Han Dynasty: "Salt and iron are all returned to the people. Then Good governance is also good." The best way to hide wealth in the people is to scorn. In this regard, Liu Bang established in the early days of the founding of the country "light field rent, the fifth and the tax one, the amount of money, the official use, to the people." Wrong also said to the Chinese emperor: "according to the people, the three: One "Let the people go out to rent the land, 30 and the tax is also one." Most of the rulers of the Western Han Dynasty implemented the ruling policy of "slightly and thinly", avoiding the tyranny of the "thickness of the thick knife", the "revenge of the field" and the "question of the harsh city".

\section{Conclusion}

In his political theory, Xunzi elaborated on Wang Dao and hegemonic thoughts, summed up the core characteristics of Wang Dao and hegemony in the new situation, and put forward the political proposition of "Wang Pa miscellaneous use". Although this did not cause repercussions before the death of the scorpion, it had a profound impact on the later Han Dynasty and even the entire ancient Chinese political history. Modern scholar Tan Sitong once said: "The study of the past two thousand years, dropouts are also." Deeply reveals the powerful vitality of Xunzi's thought in feudal orthodox society.

Like other Confucian scholars, Xunzi regards Wang Dao as the highest political ideal. But Xunzi is good at extracting nutrients from objective reality and improving their political line. From this point of view, the Confucianism led by Xunzi has moved from the utopianism to the dynasty practice politics. The scorpion and the strength of the hundred families, the superiority of the various factions, overcomes the weakness of Confucius and Mencius's "farming and broader than things." For the later generations, especially the rulers of the Han Dynasty, they provided a complete set of ideological and political theory systems, and also gave Confucian political philosophy a special adaptability to the times. 


\section{References}

[1] [Han] Ban Gu. Han Shu [M]. Beijing: Zhonghua Book Company, 2012.

[2] [Qing] Wang Xianqian. The solution of Xunzi [M]. Beijing: Zhonghua Book Company, 1988.

[3] [Han] Sima Qian. Shi Ji [M]. Beijing: Zhonghua Book Company, 1982.

[4] Ge Zhaoguang. History of Chinese Thought [M]. Shanghai: Fudan University Press, 2001.

[5] Tan Jiajian, Zheng Junhua. Outline of prose in pre-Qin [M]. Taiyuan: Shanxi People's Publishing House, 1987.

[6] Fu Zheng. Comparison of Prose in the Pre-Qin Period [J].Journal of Wuzhou University (Philosophy and Social Sciences).1995(03)

[7] Ren Jiyu. History of the development of Chinese philosophy [M]. Beijing: People's Publishing House, 1985.

[8] Jin Chunfeng. History of Thoughts in the Han Dynasty [M]. Beijing: China Social Sciences Press, 1987. 